\title{
Developing and Validating the Community-Oriented Frailty Index (COM-FI)
}

Ian W. Garner' ${ }^{1}$, and Adrian P. Burgess ${ }^{1,2}$, and Carol A. Holland ${ }^{3}$,

\author{
${ }^{1}$ Aston Research Centre for Healthy Ageing, Aston University, Birmingham, B4 7ET, UK \\ ${ }^{2}$ Department of Psychology, Aston University, Birmingham, B4 7ET \\ ${ }^{3}$ Centre for Ageing Research, Division of Health Research, Lancaster University, Lancaster, \\ LA1 4YG, UK
}

Corresponding Author: Ian Garner

E-Mail Address: garneri@aston.ac.uk

Address: MB624 (Life and Health Sciences), Aston University, Aston Express Way, Birmingham, West Midlands, B4 7ET

\section{Research Highlights}

- The Community-Oriented Frailty Index (COM-FI) is a valid and reliable tool, comparable to other frailty indices.

- The COM-FI incorporates a large psychological component to assess frailty, as well as physical and medical indices.

- The COM-FI is a tool for use in integrated care settings where there may not be access to medical records.

- COM-FI prognostic capabilities include predicting need for care.

- The COM-FI offers a platform to build towards a holistic frailty tool.

Key Words: Frailty Index; Community; COM-FI; Validation; Predicting Social Care 


\section{Acknowledgements}

The authors are grateful to the participants who took part in the study. We would also like to acknowledge all the researchers who have assisted in gathering data for the larger longitudinal study over the last 7 years.

The authors are grateful to The ExtraCare Charitable Trust for the funding of the underlying longitudinal study and for co-funding this project with Aston University as part of an Anniversary award PhD studentship. 


\begin{abstract}
Introduction

Methods for measuring frailty over-emphasise physical health, and consensus for a more holistic approach is increasing. However, holistic tools have had mixed success in meeting the validation criteria required of a frailty index. We report on the further development and validation of a Frailty Tool designed for use in the community with a greater emphasis on psychological markers, Holland et al's Community-Oriented Frailty Index (COM-FI).
\end{abstract}

\title{
Method
}

A total of 351 participants aged 58-96 were recruited from Retirement Villages and local communities across the West Midlands of the UK. Participants completed a series of measures designed to assess frailty and outcomes associated with frailty over a 2-year period.

\section{Results}

All three candidate items ('polypharmacy', 'exercise frequency', and the Coronary Heart Disease and Diabetes 'joint effect') were incorporated into the tool, and one variable, 'falls' was removed from the index. The revised COM-FI was shown to be valid and met Rockwood's validation criteria (Rockwood et al., 2005), with the exception that in this specific sample there was no significant gender difference and the index did not predict mortality.

\section{Discussion}

Overall, the COM-FI is a valid and reliable tool, although the capacity for the COM-FI to predict mortality over a 2-year period remains inconclusive given the small numbers of people at the higher ends of the frailty range. Prediction of need for social care was good, showing the utility of this community based tool. 


\section{Introduction}

Frailty is a multidimensional, pre-disability syndrome, defined as a heightened state of vulnerability to adverse outcomes when exposed to a stressor, such as having a fall (Clegg Young, Iliffe, Rikkert, \& Rockwood, 2013), that can result in a significant reduction to quality of life (Kojima, Iliffe, Jivraj, \& Walters, 2016). The transition from robust to frail is a process of deterioration that occurs over an extended period of time predisposes individuals to disability, loss of independence, and increases the risk of hospitalisation, health care use, dementia, poor quality of life, and mortality (Rockwood, Mitnitski, Song, Steen, \& Skoog, (2006).

A consensus on how best to operationalise and assess frailty remains elusive (RodriguezManas et al., 2012). Two definitions are generally accepted within clinical settings. One defines frailty as a single physical phenotype (Fried et al., 2001) and the other defines frailty as an accumulation of impairments and illnesses (Rockwood, \& Mitnitski, 2007). Each was used to build well-recognised frailty indices: the Frailty Phenotype (Fried et al., 2001), and the Canadian Study of Health and Aging frailty index respectively (CHSA; Rockwood, 2005). However, both draw criticism for their focus on physical frailty markers to determine frailty severity, and calls for a holistic approach to frailty assessment have increased (Escourrou et al., 2017). Unfortunately, indices that have attempted to build a multidimensional tool, such as the Tilburg Frailty Indicator (Gobbens et al., 2010), and the Groningen Frailty Index (Peters, Boter, Buskens, \& Slaets, 2012), have failed to meet Rockwood's validation criteria (Dent, Kowal, \& Hoogendijk, 2016). That is, there should be a significant gender difference in relation to frailty severity, frailty should be positively associated with chronological age, and the model should predict hospitalisation and death. We postulate that to build a holistic index, an existing, validated, frailty index should be amended to incorporate non-physical markers into assessment, providing this does not compromise reliability and validity of the tool.

Our frailty index, the Community-Oriented Frailty Index (COM-FI), originally developed by Holland et al (2015), utilises the accumulation of deficits foundation of frailty, meaning it is flexible to the inclusion of new markers (on the condition variables are significantly associated with frailty, Rockwood, \& Mitnitski, 2007), and is comprised of variables used in the Frailty Phenotype (Fried et al., 2001), the CSHA index (Rockwood, 2005) and the frailty 
index derived from the English Longitudinal Study of Ageing (Nazroo, \& Marshall, 2013), and contains a large psychological component in the assessment criteria (17 of the 50 variables assess psychological markers). An important prognostic strength of the tool is its ability to predict amount of formal care an individual requires based on their frailty severity. This makes it specifically useful in integrated care settings.

However, the COM-FI requires further development as the field develops, specifically by testing whether adding assessments of physical activity (which is strongly associated with higher frailty severity; Brinkman et al., 2018) and polypharmacy (taking four or more prescribed medications) into the model is valid. The use of either or both markers in multiple frailty indices (Fried et al., 2001; Gobbens et al., 2010; Martins et al., 2019; Peters et al., 2012; Rockwood, \& Mitnitski, 2007) warrants them an a priori status. The original inclusion of 'falls' as a predictor variable is also queried, with falls considered an outcome and not a predictor (Ensrud et al., 2007).

Finally, the use of an accumulation of deficits approach to frailty assessment misrepresents the importance of severe health markers. For instance, a diagnosis of dementia is given the same weight as a diagnosis of high blood pressure (as both would receive a score of 1) despite dementia arguably being the more severe condition. Unfortunately, weighting severe markers to address this imbalance inhibits generalisability and usability of the model (Rockwood, \& Mitnitski, 2007). Therefore we suggest incorporating 'joint effects' into the model.

A joint effect is where the combined effect of specific illnesses results in a significantly worse health outcome than anticipated based on the individual effect of each illness (Köhler et al., 2012). Based on the markers used in the COM-FI, and currently identified joint effects, we considered inclusion of a Coronary Heart Disease and Diabetes joint effect, which has shown to be associated with impaired cognition (Verhargen, Borchelt, \& Smith, 2003) and increase risk of deterioration towards death (Mayer Jr et al., 2018).

These adjustments, if confirmed, would warrant re-validation of the COM-FI. Therefore, the aims of this paper are as follows: 
1. Assess suitability of candidate items for inclusion into the Frailty Index based on Rockwood and Mitnitski’s (2007) variable inclusion requirement (i.e. a significant relationship must be present between the variable and frailty).

2. Assess validity and reliability of the COM-FI using standard analytical procedures, against Rockwood's (2005) validation criteria, Holland's (2015) predictions of formal care, and Clegg et al (2013) and Kojima et al's (2016) conclusions about the impact of frailty on the risk of a fall and quality of life respectively.

\section{Method}

\section{Participants}

Data was collected as part of a larger study (Holland et al., 2015; 2018; 2019). Participants were recruited from retirement villages and local communities. Participants from the retirement villages were recruited according to how long they had lived there: baseline (recently moved in), 3, 12, 15-18, or 24 months. Assessments were repeated along the trajectory outlined up to the 2-year period. For example, if a participant's first assessment was at 12-months, they would only complete two more assessments up to the 2-year point. Of the 351 participants who took part in the project, 122 completed a single assessment, 68 completed two, 36 completed three, 114 completed four, and 11 completed five assessments.

Participants recruited from local communities were allocated to a data collection point to match the age of residents for each time point. There were 89 participants from local communities across the West Midlands of the UK (32 male, 57 female, aged 59-88) and 262 participants from 18 retirement villages (104 male, 158 female, aged 57-96), a total of 351.

Leniency was given towards the inclusion of participants under the age of 65 for two reasons. Firstly, residents living ExtraCare retirement villages have higher frailty scores on average than individuals living in local communities (Holland et al., 2015; 2017; 2019), therefore participants below the age of 65 were considered suitable for the study. Secondly, frailty is shown to develop earlier in individuals living in areas of high deprivation and health inequalities (Hanlon et al., 2018), and as the current index was developed for community use, a broader participant age range is more applicable as part of the validation procedure for the COM-FI. 


\section{Procedure}

Participants completed a series of measures and questionnaires designed to assess frailty, and frailty outcomes (formal care hours received on a weekly basis, number of falls and hospital visits over the past 12-months, and quality of life). This process was repeated at each data collection point.

\section{Ethics}

Informed consent was gained by providing participants with an information sheet outlining their rights of withdrawal and anonymity, what the study entailed, and the duty of care researchers have towards them. Participants were offered the opportunity to ask questions for verification purposes. Prior to inclusion, participants were judged to have the capacity to give informed consent under the Mental Capacity Act of 2007 and the 2 Stage Test of Capacity (Mental Capacity Act, 2008). As participants were fully briefed prior to the participation, no debriefing was required. Identifying participant information was kept on a password protected computer separate to the data files, the document itself was also password protected, and raw data was kept in a locked cabinet. All ethical procedures are aligned with BPS requirements.

\section{Measures}

Frailty and outcomes were assessed using a series of measures: a general health assessment examining participant declared diagnoses and self-rated health, grip strength, walking speed, sit-to-stand speed, and feelings of exhaustion; activities and instrumental activities of daily living (Lawton, \& Brody, 1969); hospital anxiety and depression scale (HADS; Zigmund, \& Snaith, 1983); functional limitations profile (FLP; Pollard, \& Johnston, 2001); Addenbrooke Cognitive Examination-III (ACE-III, Noone, 2015); Quality of Life (Control, Autonomy, Self-Realization, and Pleasure, CASP-12; Wiggins, Netuveli, Hyde, Higgs, \& Blane, 2008); and a 12-month medical review which included weekly exercise frequency, BMI calculation, number of falls and hospital visits, and the amount of care received (in hours) on a weekly basis. 


\section{Data Analysis}

A correlation analysis was performed between frailty and the candidate items to justify their inclusion into the COM-FI. Following this, a Cronbach's Alpha analysis was performed to assess the internal consistency of the model. Intra-class correlations were used to determine the test-retest reliability of the scale using frailty scores collected at baseline and 3 months.

To validate the COM-FI against Rockwood's (2005) criteria, a t-test was used to assess for a significant gender difference in frailty; correlation was performed to determine if a significant relationship between frailty and age was present; and Cox regressions were performed to assess the prognostic capabilities of the COM-FI in determining if the model predicted risk of hospitalisation and death up to 2-years after their first assessment was completed. In cases where participants did not complete 2-years of assessments retirement village staff were contacted to provide an update if the participant was living or had died up until the 2-year point following their first assessment was reached.

As Holland et al (2015) found that the original COM-FI significantly predicted amount of formal care needed, to ensure this capability was not lost during the development process, a Cox Regression was also performed to determine if the developed COM-FI predicted need for formal care.

The impact of frailty progression on quality of life (Kojima et al., 2016) and likelihood of a fall (Clegg et al., 2013) is well established. This means if the COM-FI predicted both outcomes this would further support the notion the model is valid and reliable.

The sensitivity and specificity of the COM-FI predicting the need for care, having a fall, hospitalisation, and death was determined using Receiver Operating Curves.

With the exception of the intra-class correlation (which was conducted on participants who completed an assessment at both baseline and 3 months), and the Cox Regressions and Receiver Operating Curves (which both used all data points to assess prognostic validity), all analyses were performed using the participant's final assessment, so that attrition over the period did not affect the analyses.

Data was analysed using SPSS Version 25. 


\section{Results}

\section{Candidate Item Inclusion}

Frailty scores gained from the COM-FI (with the 'falls' variable removed) were significantly negatively correlated with 'exercise frequency' $(\mathrm{r}=-.431, p<.001)$, and significantly positively correlated with 'polypharmacy' $(\mathrm{r}=.379, p<.001)$ and 'Coronary Heart DiseaseDiabetes joint effect' $(\mathrm{r}=.209, p<.001)$. Therefore, Rockwood's (2005) item inclusion criteria were met and the items were included into the COM-FI, producing a 52-item model (see Appendix One), which is used in the following analyses.

\section{Descriptive Statistics}

The number of participants, mean, and standard deviation of the variables: frailty, age, quality of life, care requirements, and number of falls and times hospitalised over the 12 months prior to assessment are displayed in Table 1. Quality of Life was added at a later point and so there are fewer people with that assessment, and numbers of falls and hospitalisation questions were not answered by all participants. Participant's demographic data regarding sex, age, ethnicity, and socioeconomic status can be viewed in Appendix 2.

Table 1: A Table Displaying the Number of Participants, Mean, and Standard Deviation, of Participant Age, Frailty, and Outcomes.

\begin{tabular}{llccc}
\hline & & $\boldsymbol{n}$ & Mean & Std. Dev. \\
\hline ExtraCare & Frailty (52-item) & 264 & .219 & .130 \\
& Age & 262 & 76.82 & 8.32 \\
& Quality of Life & 90 & 37.04 & 7.16 \\
& Care Received (Hours/Week) & 231 & 1.14 & 5.66 \\
& Number of Falls (previous 12 months) & 166 & .34 & 1.04 \\
& Hospitalisation (previous 12 months) & 176 & .61 & 1.86 \\
\hline & Frailty (52-item) & 87 & .108 & .075 \\
& Age & 87 & 72.72 & 6.06 \\
& Quality of Life & 63 & 40.03 & 4.87 \\
\cline { 2 - 3 } & Community & 86 & 0 & 0
\end{tabular}




\begin{tabular}{llccc}
\hline & Number of Falls (previous 12 months) & 84 & .24 & 1.35 \\
& Hospitalisation (previous 12 months) & 85 & .09 & .29 \\
\hline \multirow{3}{*}{ Total } & Frailty (52-item) & 351 & .191 & .127 \\
& Age & 349 & 75.8 & 8.01 \\
& Quality of Life & 153 & 38.27 & 6.47 \\
& Care Received (Hours/Week) & 317 & .83 & 4.86 \\
& Number of Falls (previous 12 months) & 250 & .31 & 1.15 \\
& Hospitalisation (previous 12 months) & 261 & .441 & 1.55 \\
\hline
\end{tabular}

Examination of Table 1 shows that participants in the ExtraCare cohort were both, on average, older and frailer when compared to the community cohort.

\section{Test-Retest Reliability}

A total of 164 participants had measures at baseline and 3 months. Test-retest reliability of the COM-FI was assessed using a two-way mixed-effects intra-class correlation with absolute agreement. The mean intra-class reliability (averaged across all items) was .910 (95\% C.I. .875 - .935), indicating 'very good' to 'excellent' consistency between the frailty scores from the two assessments.

\section{Internal Reliability}

The Cronbach's Alpha score was .817, and the 'alpha if item deleted' scores ranged from .799 to .827 , indicating high internal reliability with low risk of item redundancy (Pallant, 2011).

\section{Concurrent Validity}

There was no significant gender difference in frailty $(\mathrm{t}=.876, p>.05)$. However, there was a significant positive correlation between frailty and chronological age $(\mathrm{r}=.232, p<.01)$, and frailty significantly predicted quality of life $\left(\mathrm{R}^{2}=.409, \mathrm{~F}(1,151)=104.6931, p<.001\right)$. 


\section{Prognostic Validity}

For the Cox Regressions, participant frailty scores were grouped into ranges of frailty to assess the increased risk of needing formal care, having a fall, being hospitalised, and dying within 2-years based on each participant's first frailty score. Participants with a frailty score above 0.5 were removed from the analysis as the sample for those respective groups was not sufficient to draw meaningful conclusions (eight persons). As predicting risk of death over a 2-year period requires at least two data collection points, only 246 participants were eligible for analysis. From the participants eligible for analysis, 40 received formal care, 104 had a fall, 79 had been hospitalised, and 19 died over the following two years from their first assessment (a further breakdown of the percentage of participants in which the 'event' occurred based on their frailty category is provided in Appendix 3). Results are displayed in Table 2.

Table 2: Cox Regressions Assessing the Prognostic Capabilities of the COM-FI in Predicting Risk of Formal Care, Falls, Hospitalisation, and Death over a 2-Year Period.

\begin{tabular}{|c|c|c|c|c|c|c|c|c|c|c|}
\hline & \multirow{2}{*}{$\begin{array}{r}\text { Frailty } \\
\text { Groups }\end{array}$} & \multirow[t]{2}{*}{$n$} & \multirow[t]{2}{*}{ B } & \multirow[t]{2}{*}{ SE } & \multirow[t]{2}{*}{ Wald } & \multirow[t]{2}{*}{ df } & \multirow[t]{2}{*}{ Sig. } & \multirow[t]{2}{*}{$\operatorname{Exp}(B)$} & \multicolumn{2}{|c|}{$95 \% \mathrm{CI}$} \\
\hline & & & & & & & & & Lower & Upper \\
\hline \multirow{5}{*}{ Need Care } & $0.0-0.1$ & 95 & & & 51.042 & 4 & $<.001$ & & & \\
\hline & $0.1-0.2$ & 105 & 1.504 & 1.096 & 1.886 & 1 & .170 & 4.501 & .526 & 38.537 \\
\hline & $0.2-0.3$ & 65 & 2.513 & 1.061 & 5.611 & 1 & .018 & 12.344 & 1.543 & 98.752 \\
\hline & $0.3-0.4$ & 26 & 4.129 & 1.034 & 15.933 & 1 & $<.001$ & 62.119 & 8.179 & 471.781 \\
\hline & $0.4-0.5$ & 17 & 4.258 & 1.046 & 16.558 & 1 & $<.001$ & 70.686 & 9.090 & 549.666 \\
\hline \multirow{5}{*}{ Death } & $0.0-0.1$ & 75 & & & 9.822 & 4 & .044 & & & \\
\hline & $0.1-0.2$ & 85 & 11.551 & 127.498 & .008 & 1 & .928 & --- & --- & --- \\
\hline & $0.2-0.3$ & 51 & 10.486 & 127.502 & .007 & 1 & .934 & --- & --- & --- \\
\hline & $0.3-0.4$ & 17 & 11.220 & 127.501 & .008 & 1 & .930 & --- & --- & --- \\
\hline & $0.4-0.5$ & 4 & 13.071 & 127.498 & .011 & 1 & .918 & --- & --- & --- \\
\hline \multirow{5}{*}{ Falls } & $0.0-0.1$ & 102 & & & 17.793 & 4 & .001 & & & \\
\hline & $0.1-0.2$ & 116 & .542 & .287 & 3.572 & 1 & .059 & 1.719 & .980 & 3.015 \\
\hline & $0.2-0.3$ & 72 & .912 & .299 & 9.333 & 1 & .002 & 2.489 & 1.387 & 4.469 \\
\hline & $0.3-0.4$ & 30 & .909 & .381 & 5.690 & 1 & .017 & 2.482 & 1.176 & 5.237 \\
\hline & $0.4-0.5$ & 19 & 1.532 & .371 & 17.020 & 1 & $<.001$ & 4.628 & 2.235 & 9.583 \\
\hline \multirow{5}{*}{ Hospitalisation } & $0.0-0.1$ & 95 & & & 18.415 & 4 & .001 & & & \\
\hline & $0.1-0.2$ & 108 & .570 & .255 & 5.011 & 1 & .025 & 1.768 & 1.073 & 2.912 \\
\hline & $0.2-0.3$ & 65 & .626 & .282 & 4.920 & 1 & .027 & 1.871 & 1.076 & 3.254 \\
\hline & $0.3-0.4$ & 26 & 1.306 & .313 & 17.372 & 1 & $<.001$ & 3.691 & 1.997 & 6.820 \\
\hline & $0.4-0.5$ & 18 & .866 & .390 & 4.926 & 1 & .026 & 2.378 & 1.107 & 5.109 \\
\hline
\end{tabular}


With the exception of predicting death, the COM-FI significantly predicted all outcomes, with the frailest participants $(0.4-0.5)$ being $70.69 x$ more likely to need care, $4.63 x$ more likely to have a fall, and 2.38x more likely to be hospitalised compared to the most robust participants.

\section{Receiver Operating Curves}

The area-under-the-curve (AUC), sensitivity and specificity in predicting the risk of needing care, having a falls, being hospitalised, and death are displayed in Table 3.

Table 3: Area under the Curve, Sensitivity and Specificity in Relation to the COM-FI Predicting Need for Care, Death, Falls, and Hospitalisation.

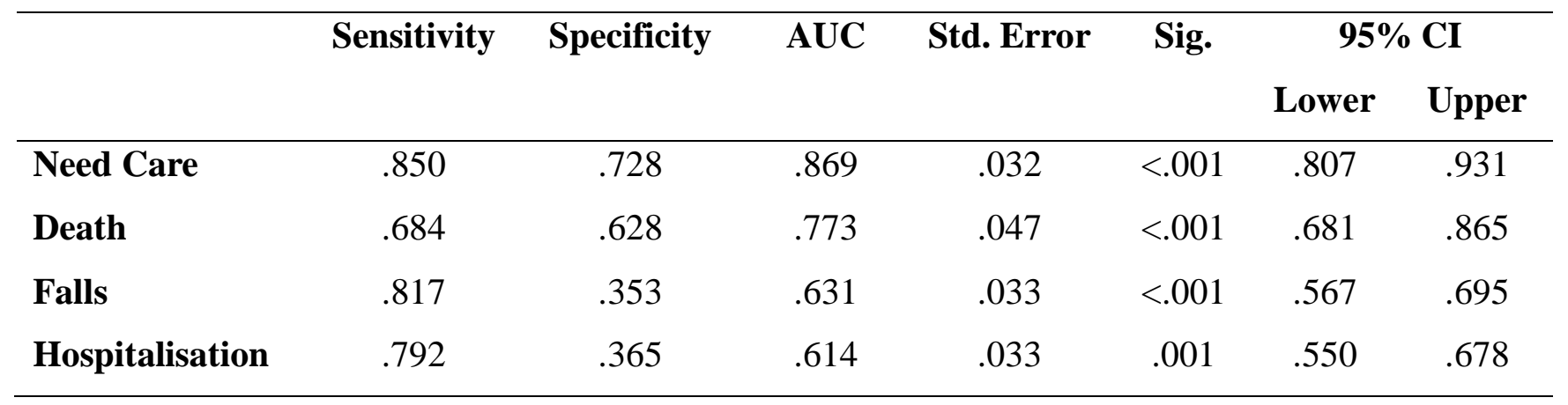

Under the 'area' scoring criteria set by Marŏco et al (2011), the COM-FI is a good model for predicting the need for care (as it scores above .800) and an acceptable model for predicting death, falls, and hospitalisation (scoring between .500 to .800 ). The sensitivity for all outcomes is acceptable (above .600), however the specificity for falls and hospitalisation is low (below .600), indicating a risk of false confirmation of these outcomes occurring.

\section{Discussion}

The purpose of this study was to develop and validate the frailty index designed by Holland et al (2015), known as the COM-FI, based on standard analytical methods, Rockwood's 
(2005) validation criteria, and findings from additional research (Clegg et al., 2013; Holland et al., 2015; Kojima et al., 2016).

All candidate items were added into the COM-FI and falls was removed to be used as an outcome variable. Additionally, direction is offered for addressing the added vulnerability related to joint effects of specific co-morbidities.

With the exception of a gender difference and predicting death, all of Rockwood's (2005) validation criteria were met. Results also supported previous work as the updated COM-FI predicted need for formal care (Holland et al., 2015), risk of having a fall (Clegg et al., 2013), and quality of life (Kojima et al., 2016) respectively. These findings further indicate the COM-FI possesses high levels of reliability and validity.

It is possible that the non-significant gender difference is due to a significant portion of the sample being recruited from retirement villages ( $74 \%$ of the sample), where residents are generally frailer and live with more co-morbidities than age-matched people living in their original homes (Holland et al., 2015). Being a specific population, there may be more men with higher levels of frailty than would normally be expected. This may also explain the relatively low relationship between frailty and age: according to Mitnitski et al (2005) residents of care institutions display a lower relationship between frailty and age because they are somewhat selected for frailty by the nature of their residence.

We can attribute the lack of prognostic capabilities using the Cox procedure in predicting death to the omission of participants with severe frailty scores. That is, the maximum frailty score used in the analysis was 0.5 (due to insufficient sample with a frailty score above 0.5 ), yet near end-of-life outcomes are attributed to frailty scores closer to 0.7 . Therefore, to appropriately assess the prognostic capabilities of the Frailty Index using the Cox procedure, a larger sample with more people with severe frailty is required. Further analysis with this sample over a longer period, would also be useful. However, the area-under-the-curve for prediction of mortality was good, and comparable to other tools (e.g. SHARE FI; Theou, Brothers, Mitnitski, \& Rockwood, 2013), and the COM-FI's more practical utility for planning care needs is evident.

\section{Limitations}


The low specificity of the COM-FI in predicting the risk of falls and hospitalisation indicates a level of risk of incorrectly identifying these outcomes as occurring. An important limitation is that the COM-FI, with 52 variables, is a time-consuming process, and requires variable reduction to improve usability and time efficiency. In addition, the use of an ExtraCare cohort which is, on average, frailer than community-dwelling individuals (Holland et al., 2015; 2017; 2019) may produce a stronger association between frailty and outcomes considered in this study than if the sample consisted primarily of community-dwelling participants.

\section{Conclusion}

All candidate items considered for inclusion as part of the development process were justified. Proceeding from this, with the exception of gender differences and predicting mortality (albeit with specific population circumstances), all of Rockwood's (2005) validation criteria were met. On this basis, it is reasonable to conclude that the COM-FI is a valid and reliable instrument for measuring frailty without the need for access to medical records and taking a more holistic approach, but there remains some scope for further improving the index for use in practice. 


\section{References}

Brinkman, S., Voortman, T., Kiefte-de Jong, J. C., van Rooij, F. J., Ikram, M. A., Rivadeneira, F., ... \& Schoufour, J. D. (2018). The association between lifestyle and overall health, using the frailty index. Archives of gerontology and geriatrics, 76, 8591.

Clegg, A., Young, J., Illife, S., Rikkert, M. O., \& Rockwood, K. (2013). Frailty in elderly people. The Lancet, 381(9868), 752-762.

Dent, E., Kowal, P., \& Hoogendijk, E. O. (2016). Frailty measurement in research and clinical practice: a review. European Journal of Internal Medicine, 31, 3-10.

Ensrud, K. E., Ewing, S. K., Taylor, B. C., Fink, H. A., Stone, K. L., Cauley, J. A., ... \& Cawthon, P. M. (2007). Frailty and risk of falls, fracture, and mortality in older women: the study of osteoporotic fractures. The Journals of Gerontology Series A: Biological Sciences and Medical Sciences, 62(7), 744-751.

Escourrou, E., Cesari, M., Chicoulaa, B., Fougère, B., Vellas, B., Andrieu, S., \& Oustric, S. (2017). How older persons perceive the loss of independence: the need of a holistic approach to frailty. The Journal of Frailty and Aging, 6(2), 107-112.

Fried, L. P., Tangen, C. M., Waltson, J., Newman, A. B., Hirsch, C., Gottdeiner, J., Seeman, T., Tracy, R., Kop, W. J., Burke, G., \& McBurnie, M. A. (2001). Frailty in older adults: evidence for a phenotype. Journal of Gerontology, 56(3), M146-M156.

Gobbens, R. J., van Assen, M. A., Luijkx, K. G., \& Schols, M. G. (2012). Testing an integral conceptual model of frailty. Journal of Advanced Nursing, 68(9), 2047-2060.

Holland, C., Boukouvalas, A., Wallis, S., Clarkesmith, D., Cooke, R., Liddell, L., \& Kay, A. (2017). Transition from community dwelling to retirement village in older adults: cognitive functioning and psychological health outcomes. Ageing \& Society, 37(7), 1499-1526.

Holland, C., Garner, I., O’Donnell, J., \& Gwyther, H. (2019). Integrated Homes, Care and Support. 
Holland, C., West, K., Shaw, R., Cooke, R., Collins, J., Hagger, B., Wallis, S., Liddell, L., Kay, A., Clarkesmith, D., Carter, M., Powell, R. and Leask, G. (2015). Collaborative Research between Aston Research Centre for Healthy Ageing (ARCHA) and the ExtraCare Charitable Trust, http://www.aston.ac.uk/lhs/research/centresfacilities/archa/extracare-project/

Köhler, M., Kliegel, M., Kaduszkiewicz, H., Bachmann, C., Wiese, B., Bickel, H., ... \& Pentzek, M. (2012). Effect of cardiovascular and metabolic disease on cognitive test performance and cognitive change in older adults. Journal of the American Geriatrics Society, 60(7), 1286-1291.

Kojima, G., Iliffe, S., Jivraj, S., \& Walters, K. (2016). Association between frailty and quality of life among community-dwelling older people: a systematic review and metaanalysis. Journal of Epidemiology \& Community Health, 70(7), 716-721.

Lawton, M. P., \& Brody, E. M. (1969). Assessment of older people: self-maintaining and instrumental activities of daily living. The Gerontologist, 9(3), 179-186.

Maroco, J., Silva, D., Rodrigues, A., Guerreiro, M., Santana, I., \& de Mendonça, A. (2011). Data mining methods in the prediction of Dementia: A real-data comparison of the accuracy, sensitivity and specificity of linear discriminant analysis, logistic regression, neural networks, support vector machines, classification trees and random forests. BMC research notes, 4(1), 299.

Martins, B. A., Visvanathan, R., Barrie, H., Huang, C. H., Matsushita, E., Okada, K., ... \& Kuzuya, M. (2019). Frailty prevalence using Frailty Index, associated factors and level of agreement among frailty tools in a cohort of Japanese older adults. Archives of gerontology and geriatrics, 84, 103908.

Mayer Jr, O., Bruthans, J., Seidlerová, J., Karnosová, P., Vaněk, J., Hronová, M., ... \& Filipovský, J. (2018). Prospective study of metabolic syndrome as a mortality marker in chronic coronary heart disease patients. European journal of internal medicine, 47, $55-61$.

Mental Health Act (2007). Ch. 12. Retrieved from: https://www.google.co.uk/search?ei=4BafWsyiDZHvgAaT3KewDw\&q=mental+heal 
th+act+2007+\&oq=mental+health+act+2007+\&gs_l=psy-

ab.3..0i71k118.12558.12558.0.12711.1.1.0.0.0.0.0.0..0.0...0...1c.1.64.psy-

ab..1.0.0....0.S-Jj36P0yi4

Mitnitski, A., Song, X., Skoog, I., Broe, G. A., Cox, J. L., Grunfeld, E., \& Rockwood, K. (2005). Relative fitness and frailty of elderly men and women in developed countries and their relationship with mortality. Journal of the American Geriatrics Society, 53(12), 2184-2189.

Nazroo \& Marshall (2013). Measuring frailty: A comparison of Fried's frailty phenotype and Rockwood's frailty index using the English Longitudinal Study of Ageing (ELSA). The Gerontologist, 53(1), 107.

Noone, P. (2015). Addenbrooke's cognitive examination-III. Occupational Medicine, 65(5), 418-420.

Office for National Statistics (2016). The National Statistics Socio-economic Classification (NS-SEC). Retrieved from: https://www.ons.gov.uk/methodology/classificationsandstandards/otherclassifications/ thenationalstatisticssocioeconomicclassificationnssecrebasedonsoc2010

Pallant, J. (2011). SPSS Survival Manual 4th edition: A step by step guide to data analysis using SPSS version 18. Maidenhead, Berkshire: Open University Press.

Peters, L. L., Boter, H., Buskens, E., \& Slaets, J. P. (2012). Measurement properties of the Groningen Frailty Indicator in home-dwelling and institutionalized elderly people. Journal of the American Medical Directors Association, 13(6), 546-551.

Pollard, B., \& Johnson, M. (2001). Problems with the Sickness Impact Profile: a theoretically based analysis and a proposal for a new method of implementation and scoring. Social Science and Medicine, 52, 921-934.

Rockwood, K. (2005). What would make a definition of frailty successful? Age and Ageing, $34,432-434$.

Rockwood, K., \& Mitnitski, A. (2007). Frailty in relation to the accumulation of deficits. The Journals of Gerontology: Series A. 62(7), 722-727. 
Rockwood, K., Mitnitski, A., Song, X., Steen, B., \& Skoog, I. (2006). Long-term risks of death and institutionalization of elderly people in relation to deficit accumulation at age 70. Journal of the American Geriatrics Society, 54, 975-979.

Rodríguez-Mañas, L., Féart, C., Mann, G., Viña, J., Chatterji, S., Chodzko-Zajko, W., Harmand, M. G. C., Bergman, H., Carcaillon, L., Nicholson, C., Scuteri, A., Sinclair, A., Pelaez, M., Van der Cammen, T., Beland, F., Bickenbach, J., Delamarche, P., Ferrucci, L., Fried, L. P., Gutiérrez-Robelo, L. M., Rockwood, K., Artalejo, F. R., Serviddio, G., \& Vega, E. (2013). Searching for an operational definition of frailty: a Delphi method based on consensus statement. The frailty operative definitionconsensus conference project. Journal of Gerontology, 68(1), 62-67.

Theou, O., Brothers, T. D., Mitnitski, A., \& Rockwood, K. (2013). Operationalization of frailty using eight commonly used scales and comparison of their ability to predict allcause mortality. Journal of the American Geriatrics Society, 61(9), 1537-1551.

Verhaegen, P., Borchelt, M., \& Smith, J. (2003). Relation between cardiovascular and metabolic disease and cognition in very old age: cross-sectional and longitudinal findings from the berlin aging study. Health psychology, 22(6), 559.

Wiggins, R., Netuveli, G., Hyde, M., Higgs, P., \& Blane, D. (2008). The evaluation of a selfenumerated scale of quality of life (CASP 19) in the context of research on Ageing: A combination of explanatory and confirmatory approaches. Social Indicators Research, $89,61-77$.

Zigmund, A. S., \& Snaith, R. P. (1983). The hospital anxiety and depression scale. Acta Psychiatrica Scandinavica, 67(6), 361-370. Doi: 10.1111/j.1600-0447.1983.tb09716.x 


\section{Appendix 1}

\section{The Community-Oriented Frailty Index List of Variables Assessed}

\begin{tabular}{|c|c|c|c|c|}
\hline Variable & $\begin{array}{l}\text { Variable } \\
\text { Type }\end{array}$ & $\begin{array}{l}\text { Variable } \\
\text { Description }\end{array}$ & Measure & Coding \\
\hline Walking 100 & Physical & $\begin{array}{l}\text { Difficulty } \\
\text { walking } 100 \\
\text { yards }\end{array}$ & $\begin{array}{l}\text { Functional } \\
\text { Limitations } \\
\text { Profile }\end{array}$ & $\begin{array}{l}\text { Ambulatory Section. } \\
\text { Difficulty mentioned }=1\end{array}$ \\
\hline Chair Get Up & Physical & $\begin{array}{l}\text { Difficulty getting } \\
\text { up from chair }\end{array}$ & Sit/Stand & $\begin{array}{l}\text { Able }=0 \\
\text { Unable }=1\end{array}$ \\
\hline Sit-To-Stand & Physical & $\begin{array}{l}\text { Time to stand } \\
\text { up from sitting } \\
\text { position. }\end{array}$ & Sit/Stand & $\begin{array}{l}\text { (Quadrants) } \\
<2.38 \text { seconds }=0 \\
3.10 \text { to } 4.09 \text { seconds }=.25 \\
4.10 \text { to } 5.09 \text { seconds }=.50 \\
5.10 \text { to } 7.55 \text { seconds }=.75 \\
\geq 7.56 \text { seconds/unable }=1\end{array}$ \\
\hline $\begin{array}{l}\text { Exercise } \\
\text { Frequency }\end{array}$ & Physical & $\begin{array}{l}\text { How many days } \\
\text { a week do } \\
\text { participants } \\
\text { exercise } 30 \\
\text { minutes or } \\
\text { more }\end{array}$ & $\begin{array}{l}\text { Well-Being } \\
\text { Assessment }\end{array}$ & $\begin{array}{l}\text { (Quadrants) } \\
0-1 \text { times per week }=1 \\
2-3 \text { times per week }=0.66 \\
4 \text { times per week }=0.33 \\
5-7 \text { times per week }=0\end{array}$ \\
\hline Stairs & Physical & $\begin{array}{l}\text { Difficulty } \\
\text { climbing stairs }\end{array}$ & $\begin{array}{l}\text { Functional } \\
\text { Limitations } \\
\text { Profile }\end{array}$ & $\begin{array}{l}\text { Ambulatory Section. } \\
\text { Difficulty mentioned }=1\end{array}$ \\
\hline Dressing & Physical & $\begin{array}{l}\text { Being able to } \\
\text { dress oneself }\end{array}$ & $\overline{A D L}$ & $\begin{array}{l}\text { No }=1 \\
\text { Yes }=0\end{array}$ \\
\hline Walking & Physical & $\begin{array}{l}\text { Difficulty } \\
\text { walking across } \\
\text { room }\end{array}$ & $\begin{array}{l}\text { Functional } \\
\text { Limitations } \\
\text { Profile }\end{array}$ & $\begin{array}{l}\text { Ambulatory Section. } \\
\text { Difficulty mentioned }=1\end{array}$ \\
\hline Bathing & Physical & $\begin{array}{l}\text { Being able to } \\
\text { bathe oneself }\end{array}$ & ADL & $\begin{array}{l}\text { No }=1 \\
\text { Yes }=0\end{array}$ \\
\hline Eating & Physical & $\begin{array}{l}\text { Being able to } \\
\text { feed oneself }\end{array}$ & ADL & $\begin{array}{l}\text { No }=1 \\
\text { Yes }=0\end{array}$ \\
\hline Bed & Physical & $\begin{array}{l}\text { Being able to } \\
\text { get in/out of } \\
\text { bed }\end{array}$ & $\mathrm{ADL}$ & $\begin{array}{l}\text { No }=1 \\
\text { Yes }=0\end{array}$ \\
\hline Toilet & Physical & $\begin{array}{l}\text { Being able to } \\
\text { use the } \\
\text { toilet/continenc } \\
\text { e }\end{array}$ & $\mathrm{ADL}$ & $\begin{array}{l}\text { No }=1 \\
\text { Yes }=0\end{array}$ \\
\hline Hot Meal & Physical & $\begin{array}{l}\text { Difficulty } \\
\text { preparing a hot } \\
\text { meal }\end{array}$ & IADL & $\begin{array}{l}\text { Needs to have meals } \\
\text { prepared and served }(4)=1\end{array}$ \\
\hline Shopping & Physical & $\begin{array}{l}\text { Difficulty } \\
\text { shopping }\end{array}$ & IADL & $\begin{array}{l}\text { Needs to be accompanied } \\
\text { (3)/ unable to shop (4) =1 }\end{array}$ \\
\hline Telephone & Psychological & $\begin{array}{l}\text { Difficulty using } \\
\text { the phone }\end{array}$ & IADL & $\begin{array}{l}\text { Does not use telephone (4) } \\
=1\end{array}$ \\
\hline
\end{tabular}




\begin{tabular}{|c|c|c|c|c|}
\hline Medication & Psychological & $\begin{array}{l}\text { Difficulty taking } \\
\text { medication }\end{array}$ & IADL & $\begin{array}{l}\text { Is not capable of dispensing } \\
\text { own medication }(3)=1\end{array}$ \\
\hline Money & Psychological & $\begin{array}{l}\text { Difficulty } \\
\text { handling money }\end{array}$ & IADL & $\begin{array}{l}\text { Needs help with major } \\
\text { banking }(2) / \text { unable to } \\
\text { handle money }(3)=1\end{array}$ \\
\hline Housework & Physical & $\begin{array}{l}\text { Difficulty } \\
\text { completing } \\
\text { housework }\end{array}$ & IADL & $\begin{array}{l}\text { Performs light tasks but } \\
\text { can't maintain } \\
\text { cleanliness( } 3 \text { )/needs help } \\
\text { (4)/does not participate (5) } \\
=1\end{array}$ \\
\hline Self-report & Psychological & $\begin{array}{l}\text { Self-reported } \\
\text { health }\end{array}$ & $\begin{array}{l}\text { General } \\
\text { Health }\end{array}$ & $\begin{array}{l}\text { Ordinal scale } \\
\text { Poor }=1 \\
\text { Fair }=0.75 \\
\text { Good }=0.5 \\
\text { V Good }=0.25 \\
\text { Excellent }=0\end{array}$ \\
\hline Depressed & Psychological & $\begin{array}{l}\text { Depressed } \\
\text { mood }\end{array}$ & HADS & $\begin{array}{l}\text { (Based on HADs Scoring } \\
\text { Scale) } \\
\text { Score } 0-7=0 \\
\text { Score } 8-10=0.5 \\
\text { Score } 11+=1\end{array}$ \\
\hline Restless Sleep & Physical & $\begin{array}{l}\text { Waking up at } \\
\text { night }\end{array}$ & $\begin{array}{l}\text { Functional } \\
\text { Limitations } \\
\text { Profile }\end{array}$ & Sleep Section. $86=1$ \\
\hline Happy & Psychological & Feeling cheerful & HADS & $\begin{array}{l}\text { 'I feel cheerful' (11) most } \\
\text { of the time }=0\end{array}$ \\
\hline Enjoy Life & Psychological & $\begin{array}{l}\text { Enjoying things } \\
\text { in life }\end{array}$ & HADS & $\begin{array}{l}\text { 'I still enjoy the things I } \\
\text { used to enjoy' ( } 3 \text { ) definitely } \\
\text { as much/not quite as much } \\
=0\end{array}$ \\
\hline Walking Speed & Physical & $\begin{array}{l}\text { Time taken to } \\
\text { walk } 7 \mathrm{~m} \text {, in } \\
\text { seconds }\end{array}$ & $\begin{array}{l}\text { General } \\
\text { Health }\end{array}$ & $\begin{array}{l}\text { (quadrants) } \\
<0.5 \mathrm{~m} / \mathrm{sec}=1 \\
0.51 \text { to } 0.55 \mathrm{~m} / \mathrm{sec}=0.75 \\
0.56 \text { to } 0.84 \mathrm{~m} / \mathrm{sec}=0.5 \\
0.85 \text { to } 1.20 \mathrm{~m} / \mathrm{sec}=0.25 \\
>1.21 \mathrm{~m} / \mathrm{sec}=0\end{array}$ \\
\hline Day & Psychological & $\begin{array}{l}\text { Knowing the } \\
\text { date }\end{array}$ & ACE-III & $\begin{array}{l}\text { Correct }=0 \\
\text { Incorrect }=1\end{array}$ \\
\hline Month & Psychological & $\begin{array}{l}\text { Knowing the } \\
\text { month }\end{array}$ & ACE-III & $\begin{array}{l}\text { Correct }=0 \\
\text { Incorrect }=1\end{array}$ \\
\hline Year & Psychological & $\begin{array}{l}\text { Knowing the } \\
\text { year }\end{array}$ & ACE-III & $\begin{array}{l}\text { Correct }=0 \\
\text { Incorrect }=1\end{array}$ \\
\hline Weekday & Psychological & $\begin{array}{l}\text { Knowing the } \\
\text { day of the week }\end{array}$ & ACE-III & $\begin{array}{l}\text { Correct }=0 \\
\text { Incorrect }=1\end{array}$ \\
\hline $\begin{array}{l}\text { Immediate } \\
\text { Recall }\end{array}$ & Psychological & $\begin{array}{l}\text { Immediate } \\
\text { word recall }\end{array}$ & ACE-III & $\begin{array}{l}\text { Score } 3=0 \\
\text { Score less than } 3=1\end{array}$ \\
\hline Fluency & Psychological & $\begin{array}{l}\text { Verbal fluency } \\
\text { (animals and p } \\
\text { words) }\end{array}$ & ACE-III & $\begin{array}{l}\text { (quadrants) } \\
\text { Score } 7 \text { or lower }=1 \\
\text { Score } 8=0.75 \\
\text { Score } 9 / 10=0.5\end{array}$ \\
\hline
\end{tabular}




\begin{tabular}{|c|c|c|c|c|}
\hline & & & & $\begin{array}{l}\text { Score } 11=0.25 \\
\text { Score } 12+=0\end{array}$ \\
\hline $\begin{array}{l}\text { Delayed } \\
\text { Recall }\end{array}$ & Psychological & $\begin{array}{l}\text { Delayed word } \\
\text { recall }\end{array}$ & ACE-III & $\begin{array}{l}\text { (quadrants) } \\
\text { Score } 0=1 \\
\text { Score } 1=0.66 \\
\text { Score } 2=0.33 \\
\text { Score } 3=0\end{array}$ \\
\hline MMSE & Psychological & MMSE score & ACE-III & $\begin{array}{l}\text { Total score } 23 \text { or lower }=1 \\
\text { Total score } 24 \text { or higher }=0\end{array}$ \\
\hline $\begin{array}{l}\text { Blood } \\
\text { Pressure }\end{array}$ & Physical & $\begin{array}{l}\text { Low or High } \\
\text { blood pressure }\end{array}$ & $\begin{array}{l}\text { Well-being } \\
\text { nurse } \\
\text { assessment }\end{array}$ & Diagnosed $=1$ \\
\hline $\mathrm{CHD}$ & Physical & $\begin{array}{l}\text { Coronary Heart } \\
\text { Disease }\end{array}$ & $\begin{array}{l}\text { Wellbeing } \\
\text { nurse } \\
\text { assessment }\end{array}$ & Diagnosed $=1$ \\
\hline Diabetes & Physical & Diabetes & $\begin{array}{l}\text { Wellbeing } \\
\text { nurse } \\
\text { assessment }\end{array}$ & Diagnosed = 1 \\
\hline Stroke & Physical & $\begin{array}{l}\text { Whether } \\
\text { participant has } \\
\text { had a stroke }\end{array}$ & $\begin{array}{l}\text { Wellbeing } \\
\text { nurse } \\
\text { assessment }\end{array}$ & Diagnosed $=1$ \\
\hline Lung Disease & Physical & Lung Diseases & $\begin{array}{l}\text { Wellbeing } \\
\text { nurse } \\
\text { assessment }\end{array}$ & Diagnosed $=1$ \\
\hline Asthma & Physical & Asthma & $\begin{array}{l}\text { Wellbeing } \\
\text { nurse } \\
\text { assessment }\end{array}$ & Diagnosed = 1 \\
\hline Arthritis & Physical & Arthritis & $\begin{array}{l}\text { Wellbeing } \\
\text { nurse } \\
\text { assessment }\end{array}$ & Diagnosed $=1$ \\
\hline Osteoporosis & Physical & Osteoporosis & $\begin{array}{l}\text { Wellbeing } \\
\text { nurse } \\
\text { assessment }\end{array}$ & Diagnosed = 1 \\
\hline Cancer & Physical & Cancer & $\begin{array}{l}\text { Wellbeing } \\
\text { nurse } \\
\text { assessment }\end{array}$ & Diagnosed = 1 \\
\hline Parkinson's & Physical & Parkinson's & $\begin{array}{l}\text { Wellbeing } \\
\text { nurse } \\
\text { assessment }\end{array}$ & Diagnosed = 1 \\
\hline Psychiatric & Psychological & $\begin{array}{l}\text { Psychiatric } \\
\text { Disorders }\end{array}$ & $\begin{array}{l}\text { Wellbeing } \\
\text { nurse } \\
\text { assessment }\end{array}$ & $\begin{array}{l}\text { Diagnosed } \\
\text { Schizophrenic/Bipolar/Dep } \\
\text { ression }=1\end{array}$ \\
\hline Dementia & Psychological & Dementia & $\begin{array}{l}\text { Wellbeing } \\
\text { nurse } \\
\text { assessment }\end{array}$ & Diagnosed = 1 \\
\hline Eyesight & Physical & $\begin{array}{l}\text { Issues with } \\
\text { eyesight }\end{array}$ & $\begin{array}{l}\text { Wellbeing } \\
\text { nurse } \\
\text { assessment }\end{array}$ & Diagnosed = 1 \\
\hline
\end{tabular}


This is the author version of the accepted paper. The paper can be cited as Garner, I.W., Burgess, A.P., and Holland, C.A. (2020) Developing and validating the Community-Oriented Frailty Index (COM-FI) Archives of Gerontology and Geriatrics, 91, 104232, https://doi.org/10.1016/j.archger.2020.104232

\begin{tabular}{|c|c|c|c|c|}
\hline $\begin{array}{l}\text { Self-reported } \\
\text { Hearing }\end{array}$ & Physical & $\begin{array}{l}\text { Self-reported } \\
\text { hearing }\end{array}$ & $\begin{array}{l}\text { Wellbeing } \\
\text { nurse } \\
\text { assessment }\end{array}$ & Problem mentioned $=1$ \\
\hline Hip Fracture & Physical & $\begin{array}{l}\text { Has participant } \\
\text { ever had a hip } \\
\text { fracture }\end{array}$ & $\begin{array}{l}\text { Wellbeing } \\
\text { nurse } \\
\text { assessment }\end{array}$ & Fracture Recorded $=1$ \\
\hline $\begin{array}{l}\text { Joint } \\
\text { Replacement }\end{array}$ & Physical & $\begin{array}{l}\text { Has participant } \\
\text { ever had a joint } \\
\text { replacement }\end{array}$ & $\begin{array}{l}\text { Wellbeing } \\
\text { nurse } \\
\text { assessment }\end{array}$ & Replacement Recorded = 1 \\
\hline BMI & Physical & $\begin{array}{l}\text { Body Mass } \\
\text { Index }\end{array}$ & $\begin{array}{l}\text { Wellbeing } \\
\text { nurse } \\
\text { assessment }\end{array}$ & $\begin{array}{l}\text { Based on Rockwood et } \\
\text { al(2008) continuous } \\
\text { variables } \\
\text { Below } 18=1 \\
18-25=0 \\
25-30=0.5 \\
\text { Above } 30=1\end{array}$ \\
\hline Grip Strength & Physical & $\begin{array}{l}\text { Grip } \\
\text { Strength }(\mathrm{kg})\end{array}$ & $\begin{array}{l}\text { General } \\
\text { Health }\end{array}$ & $\begin{array}{l}\text { Based on Rockwood et } \\
\text { al(2008) continuous } \\
\text { variables } \\
\text { For men: Below } 30=1 \\
\text { Above } 30.1=0 \\
\text { For women: Below } 18=1 \\
\text { Above } 18.1=0\end{array}$ \\
\hline Exhaustion & Physical & $\begin{array}{l}\text { In the past } \\
\text { week, has } \\
\text { everything you } \\
\text { did felt like an } \\
\text { effort? }\end{array}$ & $\begin{array}{l}\text { General } \\
\text { Health }\end{array}$ & $\begin{array}{l}\text { Ordinal Scale } \\
\text { Rarely ( } 0 \text { days) }=0 \\
\text { Some of the time ( } 1-2 \text { days) } \\
=0.33 \\
\text { Occasionally ( } 3-4 \text { days) = } \\
0.66 \\
\text { Most or all of the time (5-7 } \\
\text { days) = } 1\end{array}$ \\
\hline Polypharmacy & Physical & $\begin{array}{l}\text { How many } \\
\text { prescribed } \\
\text { medications do } \\
\text { you take? }\end{array}$ & $\begin{array}{l}\text { Wellbeing } \\
\text { nurse } \\
\text { assessment }\end{array}$ & $\begin{array}{l}\geq 4=1 \\
<4=0\end{array}$ \\
\hline
\end{tabular}




\section{Appendix 2:}

Demographic Information of Participants.

\begin{tabular}{lccc}
\hline & ExtraCare (\%) & Community (\%) & Combined (\%) \\
\hline Sex & & & \\
Male & $103(38.8)$ & $31(35.6)$ & $134(38.1)$ \\
Female & $160(60.4)$ & $56(64.3)$ & $216(61.3)$ \\
Prefer not to say / Missing & $2(0.8)$ & $0(0.0)$ & $2(0.6)$ \\
\hline Age & & & \\
$58-60$ & $6(2.3)$ & $2(2.3)$ & $8(2.3)$ \\
$61-70$ & $66(24.9)$ & $38(43.7)$ & $104(29.5)$ \\
$71-80$ & $103(38.9)$ & $37(42.5)$ & $140(39.8)$ \\
$81-90$ & $76(28.7)$ & $10(11.5)$ & $86(24.4)$ \\
$91-96$ & $11(4.2)$ & $0(0.0)$ & $11(3.1)$ \\
Prefer not to say / Missing & $3(1.1)$ & $0(0.0)$ & $3(0.9)$ \\
\hline Ethnicity & & & \\
White British & $221(83.4)$ & $80(92.0)$ & $301(85.5)$ \\
Black British & $1(0.4)$ & $1(1.1)$ & $2(0.6)$ \\
Asian British & $2(0.8)$ & $0(0.0)$ & $2(0.6)$ \\
Other White Background & $1(0.4)$ & $0(0.0)$ & $1(0.3)$ \\
Other Black Background & $5(1.9)$ & $1(1.1)$ & $6(1.7)$ \\
Other Asian Background & $1(0.4)$ & $0(0.0)$ & $1(0.3)$ \\
Prefer not to say / Missing & $34(12.8)$ & $5(5.7)$ & $39(11.1)$ \\
\hline Socioeconomic Status/Level & & & \\
Level 1 & $52(19.6)$ & $21(24.1)$ & $73(20.7)$ \\
Level 2 & $34(12.8)$ & $30(34.5)$ & $64(18.2)$ \\
Level 3 & $65(24.5)$ & $24(27.6)$ & $89(25.3)$ \\
Level 4 & $12(4.5)$ & $5(5.7)$ & $17(4.8)$ \\
Level 5 & $12(4.5)$ & $3(3.4)$ & $15(4.3)$ \\
Level 6 & $46(17.4)$ & $2(2.3)$ & $48(13.6)$ \\
Level 7 & $17(6.4)$ & $2(2.3)$ & $19(5.4)$ \\
Level 8 & $7(2.6)$ & $0(0.0)$ & $7(2.0)$ \\
Prefer not to say / Missing & $20(7.5)$ & $0(0.0)$ & $20(2.7)$ \\
\hline & & &
\end{tabular}

Below is a description of each 'Socioeconomic Level' based on the UK Office for National Statistics Socio-economic classifications (Office for National Statistics, 2016).

\begin{tabular}{c|l} 
SES Level & SES Description \\
\hline $\mathbf{1}$ & Higher managerial, administrative and professional occupations. \\
$\mathbf{2}$ & Lower managerial, administrative and professional occupations. \\
$\mathbf{3}$ & Intermediate occupations. \\
$\mathbf{4}$ & Small employers and own account workers. \\
$\mathbf{5}$ & Lower supervisory and technical occupations. \\
$\mathbf{6}$ & Semi-routine occupations. \\
$\mathbf{7}$ & Routine occupations \\
$\mathbf{8}$ & Never worked and long-term unemployed
\end{tabular}


This is the author version of the accepted paper. The paper can be cited as Garner, I.W., Burgess, A.P., and Holland, C.A. (2020) Developing and validating the Community-Oriented Frailty Index (COM-FI) Archives of Gerontology and Geriatrics, 91, 104232, https://doi.org/10.1016/j.archger.2020.104232

\section{Appendix 3:}

Breakdown of Participant Frailty Categorisation and Frequency of 'event' occurring for Cox Regression

\begin{tabular}{|c|c|c|c|c|c|c|}
\hline & & $\mathbf{n}$ & $\begin{array}{c}\text { Need Care } \\
(\%)\end{array}$ & $\begin{array}{c}\text { Death } \\
(\%)\end{array}$ & $\begin{array}{c}\text { Falls } \\
(\%)\end{array}$ & $\begin{array}{c}\text { Hospitalisation } \\
(\%)\end{array}$ \\
\hline \multirow{5}{*}{ ExtraCare } & $1.0-0.1$ & 49 & $1(2.0)$ & $0(0.0)$ & $6(12.2)$ & $13(26.5)$ \\
\hline & $0.1-0.2$ & 93 & $5(5.4)$ & $7(7.5)$ & $28(30.1)$ & $36(38.7)$ \\
\hline & $0.2-0.3$ & 64 & $8(12.5)$ & $1(1.6)$ & $27(42.2)$ & $24(37.5)$ \\
\hline & $0.3-0.4$ & 31 & 15 (48.4) & $1(3.2)$ & $11(35.5)$ & $18(58.1)$ \\
\hline & $0.4-0.5$ & 18 & $11(61.1)$ & $5(27.8)$ & $11(61.1)$ & $9(44.4)$ \\
\hline \multirow{5}{*}{ Community } & $0.0-0.1$ & 53 & $0(0.0)$ & $0(0.0)$ & $13(24.5)$ & $12(22.6)$ \\
\hline & $0.1-0.2$ & 25 & $0(0.0)$ & $0(0.0)$ & $6(24.4)$ & $6(24.0)$ \\
\hline & $0.2-0.3$ & 8 & $0(0.0)$ & $0(0.0)$ & $1(12.5)$ & $2(25.0)$ \\
\hline & $0.3-0.4$ & 0 & $0(0.0)$ & $0(0.0)$ & $0(0.0)$ & $0(0.0)$ \\
\hline & $0.4-0.5$ & 1 & $0(0.0)$ & $0(0.0)$ & $1(100.0)$ & $1(100.0)$ \\
\hline \multirow{5}{*}{ Combined } & $0.0-0.1$ & 102 & $1(1.0)$ & $0(0.0)$ & 19 (18.6) & $25(24.5)$ \\
\hline & $0.1-0.2$ & 118 & $5(4.2)$ & $7(5.9)$ & $34(28.8)$ & $42(35.6)$ \\
\hline & $0.2-0.3$ & 72 & $8(11.1)$ & $1(1.4)$ & $28(38.9)$ & $26(36.1)$ \\
\hline & $0.3-0.4$ & 31 & $15(48.4)$ & $1(3.2)$ & $11(35.5)$ & $18(58.1)$ \\
\hline & $0.4-0.5$ & 19 & $11(57.9)$ & $5(26.3)$ & $12(63.2)$ & $9(47.4)$ \\
\hline
\end{tabular}

